\title{
KERENTANAN HIDUP PEREMPUAN PENARIK LANCANG DI KAWASAN PANTAI JAKAT KOTA BENGKULU
}

\author{
Yessilia Osira
}

Dosen Jurusan Ilmu Kesejahteraan Sosial FISIP Universitas Bengkulu

\begin{abstract}
Pulling a sailboat, locally known as nyongsong, is one of informal sector jobs at Pantai Jakat of Bengkulu city. The workers' lives depended on the job of fishermen in catching fish, whose income was uncertain. This Study shows that the number of nyongsong woman-workers was increasing, and it was dominated by women aged more than 40 years old with three to seven dependents. Even though initially the motivation of those women in doing their job was just to help their respective family's economy, the job is now playing an important role in fulfilling family need. The study shows that the nyongsong may raise vulnerability, namely: a) vulnerability of job and outcome, b) job risk, c) inability to access and manage social guarantee. However, the nyongsong was able to adapt in: a) changing the motivation to help family in fulfilling the family need, b) collecting the fish together with the fishermen, and the result would be divided for two parties, c) producing dried fish, becoming farming laborers, selling vegetables, if there was no job to do.
\end{abstract}

Key words : Sailboat pulling worker, Vulnerability

\section{PENDAHULUAN}

Penarik lancang adalah sebutan untuk orang yang bekerja membantu nelayan menarik kapal (lancang) yang baru mendarat ke tepian pantai. Atas pekerjaan tersebut, mereka mendapatkan upah berupa ikan-ikan hasil tangkapan nelayan (pada umumnya ikan-ikan yang berukuran kecil). Hasil penelitian
Yesilia Osira dan kawan kawan (2013) tentang Perlindungan Sosial bagi Pekerja Sektor Informal di Kawasan Pantai Jakat Kota Bengkulu menyebutkan bahwa perempuan penarik lancang merupakan salah satu pekerja sektor informal yang dengan mudah kita temukan di kawasan Pantai Jakat Kota Bengkulu. 
Sebagaimana pekerja sektor informal lain, mereka mengalami berbagai risiko dan kerentanan kerentanan dalam kehidupannya. Kondisi ini sesuai dengan International Confernce of Labour Statisticians (ICLS) 1993 dalam ILO (2002) yang memberi definisi bahwa informal sektor adalah :

"Unit engaged in the production of goods and services with the primary objective of generating employment and incomes to the person involved. This unist typically operate at a low level of organization, with little or no division between labour and capital as faktors of productionand on a small scale. Labour relation- where they exist-are based mostly on casual employment, kinship or personal, and sosial relation rather than contractual arrangements with formal guarantees."

Kerentanan-kerentanan yang dialami oleh perempuan penarik lancang tidak hanya berkaitan dengan proses pekerjaannya saja tetapi juga kerentanan kehidupan keluarganya baik kerentanan dalam aspek kesehatan, pendidikan, dan aspek ekonomi.
Keberadaan penarik lancang di kawasan Pantai Jakat, pada dasarnya memiliki riwayat panjang sesuai dengan keberadaan nelayan yang hidup di kawasan tersebut, sehingga kehidupan penarik lancang juga memiliki dinamikanya tersendiri termasuk nilai-nilai lokal mereka dalam menghadapi permasalahan kehidupannya.

\section{Rumusan Masalah}

Berdasarkan latar belakang diatas, maka rumusan masalah penelitian ini adalah "Bagaimana Kerentanan Hidup Perempuan Penarik Lancang di Kawasan Pantai Jakat Kota Bengkulu" Dalam penelitian ini, rumusan masalah terdiri dari sub-sub permasalahan sebagai berikut; 1) Bagaimana profil perempuan penarik lancang?, 2) Bagaimana risiko atau kerentanankerentanan yang dialami oleh perempuan penarik lancang?, 3) Bagaimana potensi dan sistem sumber perlindungan sosial bagi perempuan penarik lancang tersebut? 


\section{Tujuan dan Manfaat Penelitian}

Melalui penelitian ini diharapkan dapat menggambarkan secara jelas tentang kerentanan hidup perempuan penarik lancang di Kawasan Pantai Jakat Kota Bengkulu. Hasil penelitian ini juga dapat menjadi bahan masukan dalam pengembangan dan pengayaan obyekobyek kajian praktek pekerjaan sosial dengan masyarakat, khususnya dalam implementasi

Community

\section{Organization/Community}

Development (CO/CD) pada pekerja sektor informal.

\section{METODEPENELITIAN}

Penelitian ini menggunakan pendekatan deskriptif kualitatif yang bertujuan untuk mengetahui secara detail dan mendalam tentang Kerentanan Hidup Perempuan Penarik Lancang di Kawasan Pantai Jakat Kota Bengkulu. Penelitian kualitatif dilakukan pada latar alamiah, dimana peneliti adalah sebagai instrumen kunci, teknik pengumpulan data dilakukan secara triangulasi, analisis data bersifat induktif dan hasil penelitian kualitatif lebih menekankan makna daripada generalisasi. (Sugiyono : 2009; 15).

\section{Teknik Pengumpulan Data}

Teknik pengumpulan data yang dilakukan dalam penelitian ini meliputi: 1) Wawancara Mendalam (In-depth Interview) yang dilakukan terhadap perempuan penarik lancang dan tokoh masyarakat (nelayan) di Kawasan Pantai Jakat. 2) Observasi, terutama dilakukan dengan mengamati secara langsuang maupun tidak langsung tentang risiko atau kerentanan-kerantanan yang dialami oleh perempuan penarik lancang. 3) Studi Dokumentasi, dengan membaca dan mempelajari berbagai sumber data sekunder yang berkaitan dengan kehidupan perempuan penarik lancang.

$$
\begin{aligned}
& \text { Analisis Data } \\
& \text { Analisis data dimulai sejak } \\
& \text { merumuskan dan menjelaskan } \\
& \text { masalah, sebelum terjun di lapangan, } \\
& \text { dan berlangsung terus hingga } \\
& \text { penulisan hasil penelitian. Analisis } \\
& \text { data yang dilakukan sebelum } \\
& \text { melakukan penelitian didasarkan pada } \\
& \text { hasil studi pendahuluan, yaitu }
\end{aligned}
$$


penelitian tentang Perlindungan Sosial bagi Pekerja Sektor Informal di Kawasan Pantai Jakat Kota Bengkulu (Yessilia Osira, et al,: 2013). Datadata kegiatan studi pendahuluan yang belum memenuhi kebutuhan penelitian akan dilakukan pendataan dan analisis ulang sehingga data yang diperoleh lebih kredibel.

\section{Jadwal Penelitian}

Penelitian dilaksanakan selama 8 (delapan) bulan mulai dari Bulan April sampai November 2015, meliputi kegiatan persiapan penelitian, mengkaji profil perempuan penarik lancang, mengkaji kerentanan hidup perempuan penarik lancang, mengkaji potensi dan sistem sumber perlindungan sosial bagi perempuan penarik lancang dan menyusun laporan akhir sekaligus mempublikasikan hasil penelitian.

\section{HASIL DAN PEMBAHASAN}

Profil Perempuan Penarik Lancang di Kawasan Pantai Jakat Kota

\section{Bengkulu}

Istilah perempuan penarik lancang sebenarnya merupakan istilah bahasa Indonesia yang menggambarkan sosok perempuan di pantai yang ikut menarik kapal nelayan mendarat setelah menangkap ikan di laut. Hasil penelitian ini menunjukkan bahwa sosok perempuan seperti gambaran tadi, dalam bahasa lokal di sekitar Kawasan Pantai Jakat dikenal dengan "nyongsong", karena memang pekerjaan perempuan tadi "menyongsong" perahu nelayan yang akan mendarat setelah menangkap ikan di laut.

Hasil penelitian ini menunjukkan bahwa sebagian besar perempuan penarik lancang di Kawasan Pantai Jakat berasal dari luar Kota Bengkulu, seperti berasal dari Kepahyang, Bengkulu Utara, Linggau, Pagar Alam dan daerah Talo meskipun ada juga yang berasal dari daerah Pasar Bengkulu. Mereka yang merupakan penduduk asli biasanya menarik lancang milik suami atau keluarganya. Sebagian besar perempuan penarik lancang tersebut berpendidikan sekolah dasar, hanya sebagian kecil yang berpendidikan sampai tingkat SLTA.

Hasil penelitian ini menunjukkan bahwa sebagian besar 
penarik lancang adalah perempuan berusia diatas 40 , sudah menikah dan mempunyai tanggungan hidup $3-7$ orang. Namun demikian ada juga perempuan penarik lancang yang berstatus belum menikah, yang berusia 13 tahun. Penarik lancang ini bekerja membantu orang tuanya yang bekerja sebagai nelayan.

Penelitian ini juga menunjukkan bahwa awalnya pekerjaan menarik lancang bukanlah pekerjaan yang digeluti oleh kaum perempuan, seperti yang dijelaskan oleh Mak Dito, salah satu tokoh perempuan di wilayah tersebut, bahwa sekitar 1980-an tidak ada perempuan dari wilayah ini yang turun ke pantai, karena dianggap tabu, tapi sekitar tahun 1990-an karena kondisi ekonomi, maka mulai ada beberapa perempuan yang turun ke pantai untuk membantu suaminya menarik lancang. Hal ini juga senada dengan pendapat Ibu Mulyana yang menjelaskan :

"Kerjo nyongsong ko lah dari duo puluh tahun yang lalu..sekitar tahun 90 an, waktu tuch lagi musim udang lobster, endak bantu suami..Kalu sebelumnyo idak bulih kami tino ikut turun pantai kalu pukek ndarek..dulu belum ado kapal lancang cak kini ko..tapi waktu itu karena endak nolong ngambik udang jadilah keterusan, nyongsong ko karena yang bawak lancang ko suami, jadi memang kareno endak bantu suami"...Kalu awak idak Cuma nyongsong ajo tapi jugo bantubongkar jaring, buek jaring untuk nangkok ikan"..."Kalo bantu suami biasonyo turun dari rumah sekitar jam setengah empek pagi..."

Pernyataan di atas mengindikasikan telah terjadi perubahan nilai-lokal yang awalnya menyebutkan "perempuan menarik lancang itu tabu" berubah menjadi perempuan manarik lancang itu tidak tabu". Perubahan ini terjadi karena tuntutan pemenuhan kebutuhan hidup penarik lancang dan keluarganya semakin meningkat.

Perkembangan selanjutnya menunjukkan bahwa pekerjaan menarik lancang ini dilakukan oleh perempuan bukan hanya yang berasal dari keluarga nelayan akan tetapi juga diminati oleh para pendatang baik yang tinggal di daerah pantai maupun yang tinggal di kelurahan lain. Bahkan jumlah mereka lebih banyak dibandingkan dari penduduk asli, 
karena motif ekonomi, mencari pada konsep kerentanan yang tambahan pendapatan untuk dikemukakan Galopin (2006), memenuhi kebutuhan keluarga, kerentanan hidup perempuan penarik meskipun keluarga mereka bukan lancang mempunyai 3 (tiga) bekerja sebagai nelayan. Hal ini komponen:

disebabkan karena tuntutan kebutuhan hidup yang semakin meningkat, sementara pendapatan suami atau keluarganya tidak mencukupi. Hal ini seperti yang dikatakan oleh Ibu Silawati:

"Ibu ko lah duo taun kerjo sebagai penyongsong ko, kareno anak endak sekolah"..."Laki ibuk kalu dapek duit idak di kasi kek ibuk, itulah ibuk kerjo ko, kareno idak endak beribut terus tiok ari, jadi biarlah ibuk cari duit jugo, kalu idak cak iko, idak bisa makan ibuk kek anak-anak ko".

\section{Kerentanan Kehidupan Perempuan}

\section{Penarik Lancang di Kawasan}

\section{Pantai Jakat Kota Bengkulu}

Perempuan penarik lancang merupakan salah satu pekerja sektor informal yang ada di Kawasan Pantai Jakat Kota Bengkulu, yang mempunyai kerentanan-kerentanan dalam bekerja maupun dalam kehidupannya (Yessilia Osira, et al; 2013). Hal tersebut juga tercermin dalam hasil penelitian ini. Mengacu
Pertama, tingkat paparan (exsposure), yaitu sejauh mana sistem (pola kehidupan komunitas) bersinggungan dengan gangguan. Penarik lancang sangat menggantungkan aktifitasnya pada nelayan yang berangkat melaut. Apabila nelayan tidak melaut dikarenakan cuaca badai, musim paceklik atau alasan lainnya maka aktifitas penarik lancang berhenti. Inilah yang menyebabkan penarik lancang mengalami ketidakpastian dalam melakukan pekerjaannya yang akibatnya juga mengalami ketidakpastian dalam pendapatan. Hal ini seperti yang diungkapkan oleh Ibu Tina :

“....Sejak 2 tahun nyongsong, kadang-kadang kerjo menjual ikan kering.....kalu ado yang melaut pegi nyongsong, kalu idak ado, idak nyongsong, tegantung cuaca...."

Kerentanan penarik lancang juga diakibatkan karena ketidakpastian hasil tangkapan nelayan. Apabila nelayan mendapatkan hasil tangkapan yang banyak, maka penarik lancang juga mendapatkan upah (berupa ikan) yang banyak juga. Tetapi sebaliknya apabila nelayan mendapatkan ikan 
sedikit, maka upah penarik lancang juga sedikit. Wujud lain dari kerentanan perempuan penarik lancang dalam pekerjaannya diantaranya seperti jatuh, kaki dan tangan kena galangan perahu/lancang karena ombak yang besar saat menyongsong lancang bahkan sampai kuku kaki lepas, badan pegal-pegal. Kerentananan fisik ini diakui oleh Ibu Karsam, yang mengatakan:

“...Risiko nyo kerjo cak iko emang ado..ayuk pernah jatuh waktu narik lancang ke daerk...sakit juga pernah...kadang kalo ayuk sakit yang ganti cari pitis tu anak ayuk yang paling tuo..."

Kedua, Tingkat kepekaan (sensitivity) yang diartikan sebagai efek atau dampak dari gangguan yang diterima baik langsung maupun tidak langsung oleh perempuan penarik lancang. Hasil penelitian menunjukkan dampak tersebut meliputi: a) Saat iklim/cuaca buruk, nelayan tidak melaut dan ini menjadikan penarik lancang tidak mendapatkan penghasilan karena tidak bekerja (menganggur), b) Pada saat hasil tangkapan nelayan banyak, upah penarik lancang juga banyak, tetapi saat hasil tangkapan nelayan sedikit maka upah penarik lancang juga sedikit, c) kecelakaan kerja seperti kuku kaki terkelupas, jatuh, badan pegal, terkena hantaman perahu yang dihempas gelombang laut menyebabkan penarik lancang libur dari pekerjaannya beberapa waktu sampai badan sehat kembali, dan terakhir d) perempuan penarik lancang tidak mendapatkan layanan jaminan sosial.

Ketiga, Kemampuan adaptasi (capacity of response), merupakan kemampuan sistem untuk menanggapi gangguan, menyeimbangkan potensi dampak yang akan muncul, memanfaatkan peluang, dan menyatu dengan konsekuensi yang kemungkinan muncul dari adanya suatu perubahan. Hasil penelitian menunjukkan bahwa pada awalnya perempuan berniat menarik lancang "sekedar membantu" keluarga yang berposisi sebagai nelayan dalam mendaratkan perahunya, tertapi perkembangan selanjutnya, menarik lancang merupakan upaya "mencari tambahan pendapatan" untuk memenuhi kebutuhan diri dan keluarganya. Kemampuan adaptasi lain dari penarik lancang yang 
menunjukkan tingkat resiliensi tinggi adalah mereka mengumpulkan ikan hasil upah menarik lancang bersamasama ikan penarik lancang yang lain kemudian menjual ikan tersebut dan hasilnya dibagikan lagi ke mereka. Hal ini dilakukan karena susahnya menjual ikan yang jumlahnya sedikit. Strategi ini merupakan upaya penarik lancang tetap bertahan dalam kehidupannya sebagai penarik lancang meskipun hasil upah kerjanya sedang sedikit. Strategi lain yang menunjukkan kemampuan beradaptasi adalah kegiatan penarik lancang membuat ikan kering, menjual ikan kering atau bekerja sebagai buruh tani, dan berjualan sayur ketika pekerjaan menarik lancang terganggu dalam waktu yang agak panjang.

Hasil penelitian ini juga menunjukkan bahwa dalam aspek pendidikan, meskipun mayoritas perempuan penarik lancang itu berpendidikan SD, tetapi anak-anak atau keluarga mereka tidak mengalami kesulitan dalam menempuh pendidikan. Hal tersebut karena ada program jaminan pendidikan dari pemerintah, baik melalui dana BOS (bantuan operasional sekolah), ada keluarga penarik lancang yang mendapatkan beasiswa, ada yang mendapatkan BLSM (bantuan langsung sosial masyarakat). Di samping itu ada juga perempuan penarik lancang yang tidak terlalu peduli dengan aspek pendidikannya, seperti dinyatakan oleh Ibu Siswarini :

"Saya di Pagar Alam sejak
kecil...tapi sekolah cuma
sampai SD.... saya tidak mau
sekolah, mau cari uang saja..."

Sementara Ibu Sumiati menyatakan bahwa sebenarnya mereka tidak mengalami kesulitan dalam menempuh pendidikan dasar, cuma dia sendiri yang tidak mau melanjutkan sekolah. Sedangkan penarik lancang yang masih berusia 13 tahun, yaitu Fatimah, menyatakan bahwa dia tidak sekolah karena membantu ibu dan ayahnya yang bekerja sebagai nelayan.

Dalam aspek kesehatan, kehidupan perempuan penarik lancang dan keluarganya tidak mengalami kesulitan yang berarti. Mereka menyatakan tidak mengalami 
kesulitan dalam mengakses atau mendapatkan pelayanan dasar kesehatan karena mereka mendapatkan jaminan kesehatan baik melalui JKN (jaminan kesehatan nasional) yang dilakukan BPJS, Jamkesmas (jaminan kesehatan masyarakat). Meskipun demikian ada juga yang mereka belum merasa terjamin kesehatannya karena kartu jaminan kesehatannya belum jadi. Ini seperti yang dinyatakan oleh Ibu Nurhija:

"dalam urusan kesehatan, kami tidak ado kesulitan...kami sudah di data untuk dapat BPJS, tapi kami lihat dikantornya belum terdaftar"...

Dalam penelitian ini ditemukan bahwa penarik lancang juga mengalami kerentanan dalam kehidupan ekonomi keluarganya. Kesulitan mendapatkan pekerjaan, kesulitan mengakses modal usaha menjadi bentuk kerentanan perempuan penarik lancang. Hal ini seperti yang diungkapkan oleh Ibu Silawati :

“....Kalau dapek kerjo emang sulit, apo lagi cak ibu ko...dak pernah dapek modal...jadi apo yang dapek dikerjokan ibu kerjokan ajo kini....".

Pendapat tentang kerentanan dalam aspek pekerjaan juga disampaikan oleh Ibu Reni yang mengatakan kesulitan karena untuk menjadi penarik lancang harus berebutan dengan pendorong (umumnya laki-laki), jadi perempuan hanya menyongsong dengan pemilik kapal yang sudah dikenalnya. Pendapat lain yang dikemukakan oleh perempuan penarik lancang adalah kesulitan dalam mendapatkan pekerjaan lain karena tidak mempunyai keterampilan khusus serta hanya berpendidikan SD sampai SMA. Secara ringkas, kerentanan hidup perempuan penarik lancang dapat dilihat pada tabel berikut : 
Tabel 1

Komponen Kerentanan Hidup Perempuan Penarik Lancang

Di Kawasan Pantai Jakat Kota Bengkulu

\begin{tabular}{|c|c|}
\hline $\begin{array}{c}\text { Komponen Kerentanan } \\
\text { (Galopin: 2006) }\end{array}$ & Temuan Lapangan \\
\hline $\begin{array}{l}\text { Tingkat paparan (exsposure), } \\
\text { yaitu sejauhmana sistem } \\
\text { (pola kehidupan komunitas) } \\
\text { bersinggungan dengan } \\
\text { gangguan. }\end{array}$ & $\begin{array}{l}\text { Dalam komunitas penarik lancang, gangguan } \\
\text { dikaitkan dengan: } \\
\text { - Perubahan iklim/cuaca dan ketidakpastian } \\
\text { nelayan melaut } \\
\text { - Ketidakpastian hasil tangkapan nelayan } \\
\text { - Kecelakaan kerja } \\
\text { - Ketidakmampuan mengakses layanan sistem } \\
\text { jaminan sosial }\end{array}$ \\
\hline $\begin{array}{l}\text { Tingkat } \\
\text { (sensitivity) yang diartikan } \\
\text { sebagai efek atau dampak } \\
\text { dari gangguan }\end{array}$ & $\begin{array}{l}\text { - Saat iklim/cuaca buruk, nelayan tidak } \\
\text { melaut dan ini menjadikan penarik lancang } \\
\text { tidak mendapatkan penghasilan karena tidak } \\
\text { bekerja (menganggur) } \\
\text { - Saat hasil tangkapan nelayan banyak, upah } \\
\text { penarik lancang juga banyak, tetapi saat } \\
\text { hasil tangkapan nelayan sedikit maka upah } \\
\text { penarik lancang juga sedikit. } \\
\text { - Kecelakaan kerja seperti kuku kaki } \\
\text { terkelupas, jatuh, badan pegal, terkena } \\
\text { hantaman perahu yang dihempas gelombang } \\
\text { laut menyebabkan penarik lancang libur dari } \\
\text { pekerjaannya beberapa waktu sampai badan } \\
\text { sehat kembali } \\
\text { Tidak mendapatkan layanan jaminan sosial }\end{array}$ \\
\hline $\begin{array}{l}\text { Kemampuan } \\
\text { (capacity of response), } \\
\text { merupakan kemampuan } \\
\text { sistem untuk menanggapi } \\
\text { gangguan, menyeimbangkan } \\
\text { potensi dampak yang akan } \\
\text { muncul, memanfaatkan } \\
\text { peluang, dan menyatu } \\
\text { dengan konsekuensi yang } \\
\text { kemungkinan muncul dari } \\
\text { adanya suatu perubahan }\end{array}$ & $\begin{array}{l}\text { - Strategi penarik lancang yang awalnya } \\
\text { bekerja karena motif membantu keluarga } \\
\text { yang bekerja sebagai nelayan dalam } \\
\text { mendaratkan perahunya, berubah menjadi } \\
\text { motif bekerja untuk memenuhi kebutuhan. } \\
\text { - Strategi penarik lancang mengumpulkan } \\
\text { ikan upah pekerjaannya bersama dengan } \\
\text { hasil penarik lancang lain, menjualnya dan } \\
\text { hasilnya dibagikan kembali pada penarik } \\
\text { lancang. } \\
\text { - Strategi penarik lancang dengan membuat } \\
\text { ikan kering, menjual ikan kering atau } \\
\text { bekerja sebagai buruh tani, berjualan sayur } \\
\text { ketika pekerjaan menarik lancang terganggu } \\
\text { dalam waktu yang agak panjang. }\end{array}$ \\
\hline
\end{tabular}

Sumber: Hasil penelitian, 2015 
Potensi dan Kemampuan Perlindungan Sosial bagi Perempuan Penarik Lancang di Kawasan Pantai Jakat Kota Bengkulu

Meskipun kehidupan perempuan penarik lancang di Kawasan Pantai Jakat Kota Bengkulu mengalami berbagai permasalahan/kebutuhan akibat kerentanan-kerentanan yang ada, tetapi pada dasarnya mereka juga memiliki potensi/kemampuan dan juga sumber-sumber perlindungan sosial yang dapat dimanfaatkan untuk mengatasi permasalahan yang ada. Perlindungan sosial tersebut diartikan sebagai upaya yang diselenggarakan baik oleh pemerintah maupun masyarakat untuk mengatasi kerentanan-kerentanan kehidupan komunitas penarik lancang. Hal ini sesuai dengan pengertian Perlindungan sosial yang dikemukakan oleh Edi Suharto (2006) yang menyatakan, bahwa dalam arti luas:

"Perlindungan sosial dapat diartikan sebagai segala inisiatif baik yang dilakukan oleh pemerintah, swasta dan masyarakat yang bertujuan untuk menyediakan transfer pendapatan atau konsumsi pada orang miskin, melindungi kelompok rentan terhadap risiko-risiko kehidupan (lifelihood), dan meningkatkan status dan hak sosial kelompok-kelompok yang terpinggirkan di dalam suatu masyarakat."

Hasil penelitian ini menunjukkan bahwa penarik lancang pada umumnya mengetahui ada jaminan kesehatan (BPJS) dan jaminan pendidikan dasar (BOS) tetapi tidak semua dari mereka mampu mengaksesnya karena berbagai hambatan seperti kurangnya pengetahuan tentang mekanisme mengakses layanan, tidak masuknya data mereka dari pendataan masyarakat yang berhak mendapatkan jaminan kesehatan dan jaminan pendidikan dasar, yang dilakukan pemerintah kelurahan.

Hasil penelitian ini juga menyebutkan bahwa perempuan penarik lancang ini pernah juga mendapatkan bantuan pinjaman modal bergulir bagi kelompok/koperasi, baik dari program samisake (program pemerintah kota Bengkulu), program pengabdian 
masyarakat Universitas Bengkulu, Program Askesos dari Dinas Sosial, dan bantuan dari sumber lain untuk ibu-ibu nelayan yang karena berbagai hambatan kini tidak berjalan lagi. Hal ini seperti yang disampaikan oleh Ibu Siswarini:

“....kalo ekonomi, kami dikasih bantuan samisake....1 kelompok 10 orang, dapet 1 juta masing-masing...jadi 1 minggu dikembalikan sebesar 25 ribu...."

Keberadaan sistem sumber ini juga disampaikan oleh Ibu Mulyana:

“.....kalo dulu kami pernah ikut Program Askesos, tapi kini tidak ado lagi....kami dapek bantuan 30 juta tapi idak jelas peruntukannya..makonyo kini awak lah idak ndak lagi ikut kegiatan kelompok yang idak jelas....... yang lebih idak enak hati kareno awak meraso cuma dibodoh-bodohi ajo kek kawan sendiri......"

Hal ini terjadi karena ketua kelompok kurang transparan dalam pengelolaan, padahal Ibu Mulyana juga merupakan salah satu pengurus kelompok tersebut. Sistem sumber lain yang memberikan bantuan kepada penarik lancang berasal dari
Dinas Perikanan berupa peralatan celemek, sepatu, piber, dan topi.

Berdasarkan kerentanankerentanan tersebut, serta potensi dan sistem sumber yang ada pada kehidupan penarik lancang dan nelayan seperti nilai-nilai egaliter, kejujuran, kebersamaan, kepercayaan dan berbagai bentuk modal sosial lain (Heni Nopianti, Nia Elvina: 2011), maka diperlukan adanya pengembangan kapasitas bagi perempuan penarik lancang dan keluarganya meliputi: 1) peningkatan kapasitas meningkatkan nilai tambah pengolahan ikan, 2) peningkatan kapasitas mengakses sistem jaminan sosial dan program pemberdayaan masyarakat baik yang dilakukan oleh pemerintah maupun oleh swasta, 3) peningkatan kapasitas pengelolaan kelompok usaha dengan menggunakan modal usaha dana bergulir.

\section{KESIMPULAN}

Hasil penelitian tentang kerentanan hidup perempuan penarik lancang di kawasan Pantai Jakat Kota Bengkulu dapat disimpulkan bahwa perempuan penarik lancang di 
kawasan tersebut didominasi oleh ibu-ibu dengan usia diatas 40 tahun dengan tanggung hidup 3-7 orang. Pada awalnya mereka bekerja dengan niat membantu keluarga yang bekerja sebagai nelayan dalam mendaratkan kapal setelah melaut, namun sekarang terjadi perubahan bahwa menarik lancang merupakan sebuah pekerjaan untuk mendapatkan penghasilan guna memenuhi kebutuhan hidup keluarganya.

Hasil penelitian menunjukkan tingkat paparan kerentanan perempuan penarik lancang meliputi: a). ketidakpastian pekerjaan karena ketidakpastian nelayan melaut, b). ketidakpastian pendapatan, c). kecalakaan kerja dan d). ketidakmampuan mengakses layanan sistem jaminan sosial. Berdasarkan tingkat paparan tersebut, penarik lancang mengalami: a). Saat iklim/cuaca buruk, nelayan tidak melaut dan ini menjadikan penarik lancang tidak mendapatkan penghasilan karena tidak bekerja (menganggur), b). Saat hasil tangkapan nelayan banyak, upah penarik lancang juga banyak, tetapi saat hasil tangkapan nelayan sedikit maka upah penarik lancang juga sedikit, c). Kecelakaan kerja seperti kuku kaki terkelupas, jatuh, badan pegal, terkena hantaman perahu yang dihempas gelombang laut menyebabkan penarik lancang libur dari pekerjaannya beberapa waktu sampai badan sehat kembali, dan d). penarik lancang tidak mendapatkan layanan jaminan sosial.

Meskipun begitu, hasil penelitian menunjukkan bahwa penarik lancang mempunyai kemampuan beradaptasi yang menunjukkan tingkat resiliensi tinggi, yaitu: a). Strategi penarik lancang yang awalnya bekerja karena motif membantu keluarga yang bekerja sebagai nelayan dalam mendaratkan perahunya, berubah menjadi motif bekerja untuk memenuhi kebutuhan, b). Strategi penarik lancang mengumpulkan ikan upah pekerjaannya bersama dengan hasil penarik lancang lain, menjualnya dan hasilnya dibagikan kembali pada penarik lancang, dan c). Strategi penarik lancang dengan membuat ikan kering, menjual ikan kering atau bekerja sebagai buruh tani, berjualan sayur ketika pekerjaan menarik 
lancang terganggu dalam waktu yang agak panjang. Di samping kemampuan tersebut, kerentanan hidup penarik lancang juga dapat diantisipasi dengan berbagai program jaminan sosial baik yang diselenggarakan oleh pemerintah maupun masyarakat, namun temuan di lapangan menunjukkan sebagian penarik lancang mengalami kesulitan dalam mengakses berbagai layanan sistem jaminan sosial.

\section{SARAN}

Berdasarkan hasil penelitian tersebut, kami merekomendasikan kepada Dinas Perikanan dan Kelautan Kota Bengkulu, Kelompok Nelayan dan komunitas penarik lancang di Kawasan Pantai Jakat untuk melakukan: a). peningkatan kapasitas perempuan penarik lancang dan keluarganya dalam pengelolaan modal usaha dana bergulir, b). peningkatan kapasitas perempuan penarik lancang dan keluarganya dalam memberikan nilai tambah ekonomis atas hasil pekerjaannya sebagai penarik lancang seperti pelatihan-pelatihan pengolahan ikan. c). Meningkatkan kapasitas perempuan penarik lancang dan keluarganya dalam mengakses sistem jaminan sosial baik yang diselenggarakan pemerintah maupun swasta.

\section{DAFTAR PUSTAKA}

Gallopin GC.2006. Linkages Between Vulnerability, Resilience, and Adaptive Capacity. Global Environmental Change (vol.16) [Internet]. [diunduh2015November 22].Tersedia pada: doi:10.1016/j.gloenvcha.2006. 02.004 Global Environmental Change. vol.16 293-303.

Heni Nopianti, Nia Elvina, 2011, Modal Sosial pada Komunitas Nelayan di Pulau Baai, Studi pada Nelayan di Kelurahan Sumber Jaya Kecamatan Kampung Melayu Kota Bengkulu, Jurnal Penelitian Ilmu Sosial dan Budaya AKSES.

Millen, Anelli. Capacity Building (terjemahan bebas). 2006. Yogyakarta : Pembaharuan.

Suharto, Edi, Ph.D, 2006, Membangun Masyarakat Memberdayakan Rakyat. Kajian Strategis Pembangunan Kesejahteraan Sosial dan Pekerjaan Sosial, Edisi Kedua, Bandung. PT. Refika Aditama 
Sugiyono. 2009. Memahami

Penelitian

Kualitatif. Alfabeta. Bandung.

Yessilia Osira, Desy Afrita, NH Jaya

Putra, 2013, Perlindungan

Sosial bagi Pekerja Sektor

Informal di Kawasan Pantai

Jakat Kota Bengkulu, Jurnal

PEKSOS. 